\title{
Nghiên cứu về phụ nữ khởi nghiệp tại Việt Nam
}

\author{
Hồ Mạnh Toàn \\ SSHPA System \\ E-mail: toan@sshpa.com
}

Hà Nội, 02-12-2018

\section{Tóm tắt:}

Bài tổng quan nghiên cứu rà soát các nghiên cứu về phụ nữ khởi nghiệp tại Việt Nam. Hiện nay, số lượng các nghiên cứu về chủ đề này còn tản mát và chưa tập trung. Với sự đóng góp to lớn của người phụ nữ trong nền kinh tế, cần có nhiều nghiên cứu hơn về chủ đề này trong tương lai.

Keywords: Female entrepreneurship, Vietnam

\section{Hoạt động khởi nghiệp và người phụ nữ kinh doanh tại Việt Nam}

Kể từ sau khi Shark Tank phiên bản Việt Nam lên sóng, Shark Thái Vân Linh đã dần trở thành một hình mẫu nổi bật của người phụ nữ Việt Nam hiện đại. Trên thực tế, hình ảnh người phụ nữ Việt Nam giao thương, buôn bán không phải là hiếm trong lịch sử Việt Nam, thậm chí còn rất quan trọng vì họ là những người 'nuôi' chồng, có thể thấy qua nét khắc họa của Tú Xương:

Quanh năm buôn bán ở mom sông,

$$
\text { Nuôi đủ năm con với một chồng. }{ }^{1}
$$

Hiện nay, sự phát triển của kinh tế đã giúp những người phụ nữ khởi nghiệp, phát triển bản thân và thay đổi các giá trị xã hội.

Kể từ sau khi Việt Nam được cởi trói sau Đổi Mới, các cơ hội kinh doanh được mở ra và những người Việt Nam đầu tiên khởi nghiệp đã xuất hiện từ những năm 1990. Các doanh nghiệp vừa và nhỏ này đóng góp rất lớn cho sự phát triển của kinh tế Việt Nam [1]. Sự phát triển của kinh tế cũng song hành cùng với sự phát triển của xã hội và văn hóa Việt Nam. Trong môi trường bị ảnh hưởng bởi các nền văn hóa lớn như Trung Quốc, Pháp, hay Mỹ, kinh doanh tại Việt Nam có những đặc thù văn hóa rất đặc trưng, và đặc biệt là các yếu tố đạo Khổng.

\footnotetext{
${ }^{1}$ https://www.thivien.net/Trần-Tế-Xương/Thương-vợ/poem-ZqTE_3GO97Ws9hNrgzlGIw
} 
Sự ảnh hưởng của Khổng giáo nói riêng, và Tam giáo nói chung tại Việt Nam có ảnh hưởng sâu rộng đến quan điểm, nhận thức, và hành vi của người Việt Nam về nhiều vấn đề như thương nghiệp [1], nghệ thuật [3], hay giới tính [2]. Theo đạo Khổng, người phụ nữ có những nghĩa vụ rất rõ ràng: Tam tòng, tứ đức. Xã hội Việt Nam hiện đại đi cùng với sự thay đổi hệ giá trị rõ rệt nhưng tựu chung ảnh hưởng của nó vẫn rất rõ rệt trong đời sống của người Việt Nam $[1,4]$ và người phụ nữ vẫn có vai trò quan trọng đảm bảo yên ấm trong ngôi nhà. Dù là trong giai đoạn nào, người phụ nữ Việt Nam luôn hiểu rất rõ về rủi ro và lợi ích trong mua bán [5]. Có lẽ đấy là vì sao trong giai đoạn kinh tế chuyển đổi, người phụ nữ tận dụng rất tốt các cơ hội khởi nghiệp kinh doanh, buôn bán để cải thiện đời sống gia đình [6].

\section{Nghiên cứu về phụ nữ khởi nghiệp tại Việt Nam}

Kể từ những năm 1990 đến nay, đã có nhiều nghiên cứu về phụ nữ, khởi nghiệp và các giá trị mà khởi nghiệp mang lại. Tác giả xin được tổng kết các số nghiên cứu tiêu biểu theo thời gian trong bảng sau:

\begin{tabular}{|c|r|l|}
\hline Năm & Ref & \multicolumn{1}{|c|}{ Nghiên cứu } \\
\hline 1997 & {$[6]$} & $\begin{array}{l}\text { Economic transition in China and Vietnam: Crossing } \\
\text { the poverty line is just the first step for women and } \\
\text { their families }\end{array}$ \\
\hline 2002 & {$[7]$} & $\begin{array}{l}\text { Gender and enterprise development in Vietnam under } \\
\text { Doi-Moi: issues for policy, research and training }\end{array}$ \\
\hline 2003 & {$[8]$} & $\begin{array}{l}\text { Values and skills of female entrepreneurs in Vietnam: } \\
\text { an exploratory study }\end{array}$ \\
\hline 2006 & {$[9]$} & $\begin{array}{l}\text { Entrepreneurial women as catalysts for } \\
\text { socioeconomic development in transitioning } \\
\text { Cambodia, Laos, and Vietnam }\end{array}$ \\
\hline 2006 & {$[10]$} & $\begin{array}{l}\text { Woman, Buddhist, entrepreneur: Gender, moral } \\
\text { values, and class anxiety in late socialist Vietnam }\end{array}$ \\
\hline 2012 & {$[11]$} & $\begin{array}{l}\text { Social capital and female entrepreneurship in rural } \\
\text { regions: Evidence from Vietnam }\end{array}$ \\
\hline 2013 & {$[12]$} & $\begin{array}{l}\text { Female Entrepreneurship in Asia: The Case of Japan, } \\
\text { South-Korea, Malaysia and Vietnam }\end{array}$ \\
\hline 2014 & {$[13]$} & $\begin{array}{l}\text { Female entrepreneurship in rural Vietnam: an } \\
\text { exploratory study }\end{array}$ \\
\hline 2015 & {$[14]$} & $\begin{array}{l}\text { Woman entrepreneurship in rural Vietnam: Success } \\
\text { and motivational factors }\end{array}$ \\
\hline 2015 & {$[15]$} & Female entrepreneurship: evidence from Vietnam \\
\hline 2016 & {$[16]$} & $\begin{array}{l}\text { A Review of Women's Entrepreneurship in Vietnam } \\
\text { Taking into Account Socio-Cultural Norms and the } \\
\text { Institutional Ecosystem }\end{array}$ \\
\hline
\end{tabular}




\begin{tabular}{|l|l|l|}
\hline 2016 & {$[17]$} & $\begin{array}{l}\text { Gender training and female empowerment: } \\
\text { Experimental evidence from Vietnam }\end{array}$ \\
\hline 2018 & {$[18]$} & $\begin{array}{l}\text { A comparative study of women entrepreneurship in } \\
\text { transitional economies: The case of China and } \\
\text { Vietnam. }\end{array}$ \\
\hline
\end{tabular}

Bảng 1: Các nghiên cứu tiêu biểu về phụ nữ khởi nghiệp tại Việt Nam

Có thể thấy, số lượng nghiên cứu tập trung trực tiếp vào những người phụ nữ khởi nghiệp tại Việt Nam là không quá nhiều. Trong đó, có đến tổng cộng 6 nghiên cứu được thực hiện hoàn toàn bởi những người nước ngoài $[6,8,9,10,12,18]$, còn các nghiên cứu do các tác giả người Việt đứng tên lại chỉ được công bố dưới dạng Working Paper $[7,16]$. Điều này phần nào cho thấy chủ đề phụ nữ, giới tính và khởi nghiệp vẫn còn khá mới mẻ trong nghiên cứu khởi nghiệp, kinh doanh tại Việt Nam, đồng thời, các nhà nghiên cứu Việt Nam cũng vẫn chưa thực sự chú ý đến chủ đề này bất chấp số lượng người phụ nữ khởi nghiệp khá tương đồng với số lượng nam giới [16]. Tuy nhiên, cần phải kiểm tra thêm tỉ lệ giữa các nghiên cứu về phụ nữ khởi nghiệp với nghiên cứu khởi nghiệp tại Việt Nam để có thể thấy cái nhìn rõ rệt hơn nữa.

Hầu hết các nghiên cứu đều chỉ ra rằng thông qua hoạt động khởi nghiệp, người phụ nữ có thêm những cơ hội để cải thiện đời sống hay bản thân $[6,9,12,16,18]$, đặc biệt là với những phụ nữ tại nông thôn $[11,13,14]$. Tuy nhiên, nghiên cứu cũng chỉ ra rằng [16] phụ nữ khởi nghiệp vẫn chịu lép vế nhiều hơn và các doanh nghiệp của họ dễ bị tổn thương hơn so với nam giới. Các khó khăn được chỉ ra gồm có sự ảnh hưởng của đạo Khổng [1, 4, 16], và thiếu vắng các chính sách hỗ trợ từ chính phủ [7, 9, 18].

Sự so sánh với các quốc gia cùng nền tảng văn hóa như Trung Quốc, Hàn Quốc hay Nhật Bản cũng được các học giả rất quan tâm $[6,12,18]$. Vào năm 1997, người phụ nữ tại cả Trung Quốc và Việt Nam đều coi khởi nghiệp là một cách để hỗ trợ gia đình [6]. Tuy nhiên, quan niệm này lại chỉ còn đúng phần nào tại Việt Nam trong khi những người phụ nữ khởi nghiệp tại Trung Quốc lại đang dần coi đó là cách để chứng minh năng lực và sự công nhận của xã hội [18]. Thực tế, trước đó một nghiên cứu lí thú đã bàn về quan niệm về đạo đức, cuộc sống của người phụ nữ Việt Nam sau khi có những thành công sau khởi nghiệp [10]. Nghiên cứu chỉ ra người phụ nữ đã gắn liền thành công của mình với các quan niệm đạo Phật để bảo vệ bản thân cũng như giải thích cho sự thành công của mình.

\section{Vì phụ nữ là một nửa thế giới}

Sự phát triển của kinh tế Việt Nam từ sau Đổi Mới đến nay có nhiều sự đóng góp rất lớn từ các doanh nghiệp vừa và nhỏ [19]. Chính vì thế, khởi nghiệp là cần thiết để thay đổi, tạo mới các giá trị xã hội. Sự đóng góp của những người phụ nữ trong khởi nghiệp nói chung và kinh tế nói riêng vì thế cũng cần được quan tâm và điều tra sâu rộng hơn 
nữa vì những đóng góp quan trọng của họ đối với sự phát triển của kinh tế, xã hội Việt Nam. Và quan trọng nhất, vì phụ nữ là một nửa thế giới!

\section{References:}

[1] Vuong Q. H., Tran T. D. (2009). The cultural dimensions of the Vietnamese private entrepreneurship. IUP Journal of Entrepreneurship Development, VI(3-4): 5478.

[2] Le, T. M. \& Yu, N. (2018). Ideological and philosophical underpinnings of attitudes toward sexual minorities in Vietnamese society. Sexuality \& Culture, DOI:10.1007/s12119-018-9577-4.

[3] Vuong, Q.H., Ho, M.T., Vuong, T.T., Tran, K., \& Ho, M. (2018b). "Paintings can be forged, but not feeling": Vietnamese art-Market, fraud, and value. Arts, 7(4), 62, doi:10.3390/arts7040062.

[4] Vuong, Q. H. (2016). Impacts of geographical locations and sociocultural traits on the Vietnamese entrepreneurship. SpringPlus, 5, 1189, DOI: 10.1186/s40064016-2850-9.

[5] Napier, N. K., \& Hoang, V. Q. (2013). What we see, why we worry, why we hope: Vietnam going forward. Boise: Boise State University CCI Press.

[6] Summerfield, G. (1997). Economic transition in China and Vietnam: Crossing the poverty line is just the first step for women and their families. Review of Social Economy, 55(2), 201-214.

[7] Truong, T. D. (2002). Gender and enterprise development in Vietnam under DoiMoi: issues for policy, research and training. ISS Working Paper Series/General Series, 363, 1-34.

[8] Gerrard, P., Schoch, H., \& Barton Cunningham, J. (2003). Values and skills of female entrepreneurs in Vietnam: an exploratory study. Asia Pacific Business Review, 10(2), 139-159.

[9] Ardrey IV, W. J., Pecotich, A., \& Shultz, C. J. (2006). Entrepreneurial women as catalysts for socioeconomic development in transitioning Cambodia, Laos, and Vietnam. Consumption, Markets and Culture, 9(4), 277-300.

[10] Leshkowich, A. M. (2006). Woman, Buddhist, entrepreneur: Gender, moral values, and class anxiety in late socialist Vietnam. Journal of Vietnamese Studies, 1(12), 277-313.

[11] Poon, J. P., Thai, D. T., \& Naybor, D. (2012). Social capital and female entrepreneurship in rural regions: Evidence from Vietnam. Applied Geography, 35(1-2), 308-315. 
[12] Debroux, P. (2013). Female Entrepreneurship in Asia: The Case of Japan, SouthKorea, Malaysia and Vietnam. 創価経営論集, 37(1), 1-23.

[13] Nguyen, C., Frederick, H., \& Nguyen, H. (2014). Female entrepreneurship in rural Vietnam: an exploratory study. International Journal of Gender and Entrepreneurship, 6(1), 50-67.

[14] Le, Q. V., \& Raven, P. V. (2015). Woman entrepreneurship in rural Vietnam: Success and motivational factors. The Journal of Developing Areas, 49(2), 57-76.

[15] Zhu, L., Kara, O., Chu, H. M., \& Chu, A. (2015). Female entrepreneurship: evidence from Vietnam. Journal of Business and Entrepreneurship, 26(3), 103.

[16] Anh, N. H., Giang, H. T., Tuan, D. V. H., \& Tram, H. B. (2016). A Review of Women's Entrepreneurship in Vietnam Taking into Account Socio-Cultural Norms and the Institutional Ecosystem. World Trade Institute, University of Bern, Working Paper No. 11/2016.

[17] Bulte, E., Lensink, R., \& Vu, N. (2016). Gender training and female empowerment: Experimental evidence from Vietnam. Economics Letters, 145, 117-119.

[18] Zhu, L., Kara, O., \& Zhu, X. (2018). A comparative study of women entrepreneurship in transitional economies: The case of China and Vietnam. Journal of Entrepreneurship in Emerging Economies.

[19] Vuong, Q. H. (2018). The financial economy of Viet Nam in an age of reform, 1986-2016. In Routledge Handbook of Banking and Finance in Asia (pp. 227248). 